\title{
The serum protein changes in giant cell arteritis
}

\author{
J. MICHAEL SMALL AND KETTY GAVRILESCU
}

From the Maida Vale Hospital for Nervous Diseases, London

Gilmour in 1941 first drew attention to the fact that temporal arteritis was but one facet of a general vascular disorder of unknown aetiology, giant cell arteritis. This concept gained support from Cooke, Cloake, Govan, and Colbeck (1946), Cardell and Hanley (1951), and Heptinstall, Porter, and Barkley (1954). The diversity of clinical presentation has been well reviewed by Ross Russell (1959) and by Paulley and Hughes (1960) and may include occipital pain and discomfort suggesting cervical spondylosis, meningitis, or even a subarachnoid haemorrhage. Yet a further masquerade is that of muscular stiffness and discomfort which Paulley and Hughes would equate with 'anarthritic rheumatoid disease' (Bagratuni, 1953 and 1956); this too is the view of MacGregor (1961), but it should be added that this relationship between these conditions has not been clearly demonstrated, and many, including Bagratuni, would dispute it. The disease may smoulder on unmasked until some catastrophe, such as blindness ensues; indeed Hollenhorst, Brown, Wagener, and Shick (1960) state that of 175 patients seen with this condition at the Mayo Clinic between 1931 and $1959,42 \%$ became blind in one or both eyes before the diagnosis was made, yet such visual loss might, as they indicate, have been prevented had an earlier diagnosis been made and appropriate steroid therapy recommended.

This very diversity of presentation makes the clinical diagnosis on occasion formidable. While it is well known that such patients are invariably over 45 years of age, and indeed more commonly over 60 , the E.S.R. constantly raised, a mild normocytic anaemia common, with possibly a slight leucocytosis, such factors in themselves cannot make the diagnosis. Again, too, an arterial biopsy may not inevitably disclose the appropriate histological changes and is hardly a justifiable procedure unless there are reasonable grounds for suspecting this condition.

It is the purpose of this paper to present the serum protein changes in patients with giant cell arteritis and to indicate how they may aid both in diagnosis and in assessing the activity of this condition. The value of such an investigation appears to be as yet little recognized. Hollenhorst et al. (1960) merely comment that occasional changes in the serum electrophoretic pattern may be found, while in the 35 patients reported by Ross Russell he stated that in four out of 12 patients so investigated electrophoresis showed an increase in the alpha globulin. Again, Crompton (1961) simply states that very often the plasma globulin concentration is considerably increased and that sometimes the albumin-globulin ratio is inverted. Paulley and Hughes (1960) certainly comment that serum electrophoresis often demonstrates increases in the globulin fractions, especially alpha 2 and beta, but they do not elaborate their findings, nor do they discuss it further. Only Björkman (1958) makes the firm statement that the electrophoretic pattern of the serum in this condition is abnormal, with a strikingly increased alpha 2 fraction.

\section{METHOD}

We used cellulose acetate as a supporting medium. The advantages of Kohn's technique $(1958,1960)$ are considerable in that apart from the vast time-saving factor, there is a sharp separation of the fractions, particularly of the alpha 1 globulins from the albumin.

Serum, $5 \mu \mathrm{l}$., was applied under current ( $120 \mathrm{v}$ constant) on strips $12 \times 2.5 \mathrm{~cm}$. for one and a half hours. The barbitone buffer was $p \mathrm{H} 8.6$ and ionic strength 0.05 .

The protein staining was done with $2 \mathrm{~g}$. Ponceau $\mathbf{S}$ (G. T. Gurr) in $30 \mathrm{~g} . \%$ trichloracetic acid. The glycoproteins were stained with Feulgen Schiff, according to Bodman's technique (1957).

The quantitative evaluation was done with a reflectance densitometer (Chromoscan).

\section{RESULTS}

The main clinical features and the serum protein changes in 11 patients with giant cell arteritis, all but one of whom received steroid therapy for a varying period of time, are set out in Table $I$.

A study of Table I will emphasize the way in which this condition may smoulder on, and its tendency to flare up at intervals, despite steroid therapy over many months, is well illustrated by patient A.R.

A.R. was first seen on 22 February 1961 and her symptoms responded dramatically to Prednisone, 
TABLE I

Case No. and

Date and

Place of

Admission

SALIENT FEATURES OF 11 PATIENTS WITH GIANT CELL ARTERITIS

Age (yr.)

Presenting Complaints

E.S.R.

(Westergren

in 1 hour)

\begin{tabular}{|c|c|}
\hline Serum & Protein $\mathbb{W}^{(}(A b$ \\
\hline $\begin{array}{l}\text { Average } \\
\text { Normal } \\
\text { (28) }\end{array}$ & 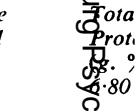 \\
\hline $\begin{array}{l}\text { Normal } \\
(28 \text { case }\end{array}$ & 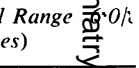 \\
\hline
\end{tabular}

1 A.R. (65) \& 22.2.6

2 H.B. (69) of $\mathbf{4 . 8 . 6 1}$

3 A.L. (65) oे 23.10 .61

4 W.R. (62) ô 20.3 .61

5 B.L. (72) क 10.10 .61

L. fronto-temporal headaches and scalp tenderness, $6 \mathrm{wk}$. Occipital and cervical discomfort, $4 \mathrm{mth}$.

Severe generalized headaches, $1 \mathrm{mth}$.

Severe generalized headaches and scalp tenderness, $6 \mathrm{wk}$.

Difficulty with gait, 10 wk., sudden loss of vision in R. eye, 2 wk.

6 W.H. (68) \& 31.5 .61

7 F.V. (74) \& 28.9 .59

8 G.J. (73) के 26.1.61

9 J.F. (79) of 29.1 .62

10 P.M. (66) क 30.10 .58

L. fronto-temporal headaches and scalp tenderness, $3 \mathrm{wk}$.

Fronto-temporal headaches, $3 \mathrm{mth}$, and sudden loss of vision $\mathrm{R}$. eye, 2 wk. $\quad 38$

Left temporal discomfort, $4 \mathrm{mth}$.

Fronto-temporal headaches, $1 \mathrm{mth}$., and scalp tenderness, 2 wk.

Temporo-occipital discomfort and diplopia on lateral gaze to either side, $6 \mathrm{wk}$.

L. fronto-temporal headaches and night sweats, $1 \mathrm{mth}$.

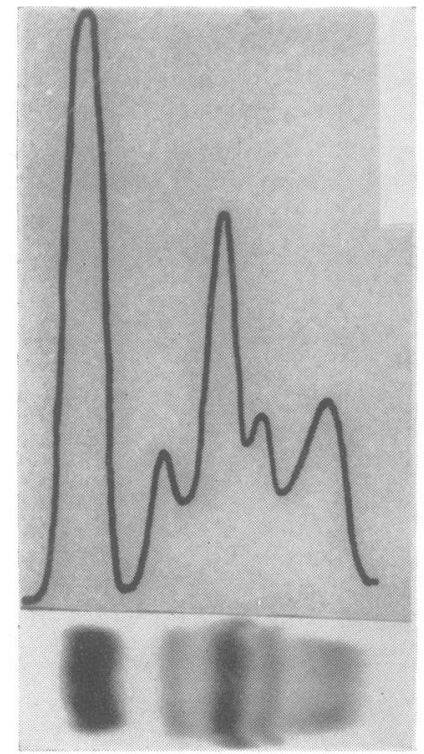

FIG. 1

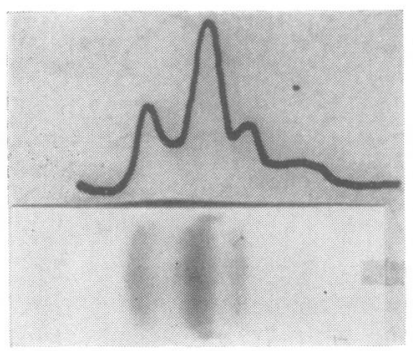

FIG. 2

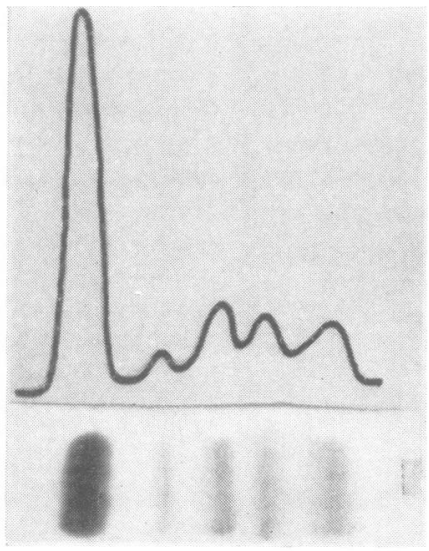

FIG. 3

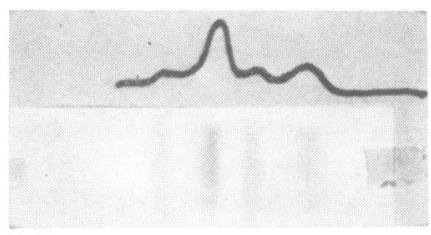

FIG. 4

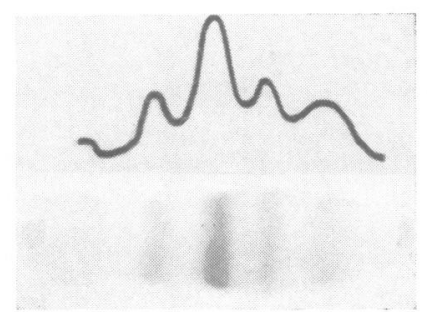

FIG. 6
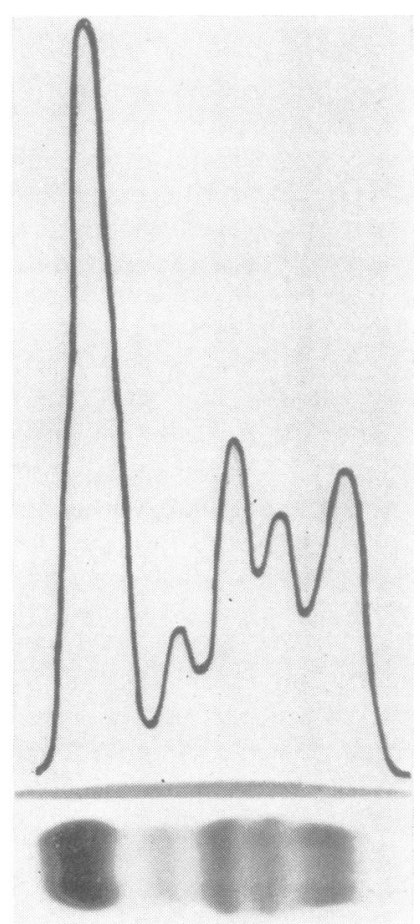

FIG. 5

FIGS. 1 to 6. Serum proteins in A.R. at different dates in her illness. 
TABLE I-continued

SALIENT FEATURES OF 11 PATIENTS WITH GIANT CELL ARTERITIS

\begin{tabular}{|c|c|c|c|c|c|c|c|c|}
\hline & \multicolumn{2}{|l|}{ Globulins } & $\beta$ & & \multirow[t]{3}{*}{$\begin{array}{l}\text { Initial } \\
\text { Dose }\end{array}$} & \multirow{3}{*}{$\begin{array}{l}\text { Average } \\
\text { Mainten- } \\
\text { ance Dose }\end{array}$} & \multirow[t]{3}{*}{$\begin{array}{l}\text { Duration } \\
\text { (mth.) }\end{array}$} & \\
\hline & $0 \cdot 28$ & 0.66 & 0.80 & 1.08 & & & & \\
\hline \multirow[t]{12}{*}{4} & $0.10 / 0.43$ & $0.41 / 0.91$ & $0.60 / 0.94$ & $0 \cdot 74 / 1 \cdot 34$ & & & & \\
\hline & 0.54 & $1 \cdot 36$ & 0.91 & $1 \cdot 20$ & 40 & 10 & 14 & 14 \\
\hline & 0.45 & $1 \cdot 15$ & 1.02 & $1 \cdot 31$ & 80 & 15 & 8 & 8 \\
\hline & 0.44 & 1.46 & 0.82 & $1 \cdot 17$ & 30 & 10 & 6 & 6 \\
\hline & 0.40 & 1.48 & 1.04 & $1 \cdot 30$ & 40 & 10 & 12 & 12 \\
\hline & 0.49 & 1.46 & 0.86 & $1 \cdot 36$ & 60 & & $1 / 52$ & $\begin{array}{l}\text { After prednisone A.C.T.H. } 40 \text { u. b.d. } \rightarrow 3.11 .61 \\
\text { Returned to Highlands Hospital }\end{array}$ \\
\hline & $0 \cdot 33$ & $1 \cdot 23$ & $0 \cdot 80$ & $1 \cdot 22$ & 30 & 15 & 9 & 9 \\
\hline & $0 \cdot 74$ & 1.47 & $1 \cdot 36$ & 1.91 & 30 & 5 & 12 & 12 \\
\hline & 0.44 & $1 \cdot 28$ & 0.89 & $1 \cdot 34$ & & & & Symptoms rapidly subsided without steroids \\
\hline & 0.47 & 1.42 & 1.01 & 0.98 & 45 & 10 & 1 & 2 \\
\hline & $0 \cdot 31$ & $1 \cdot 22$ & 0.93 & $1 \cdot 28$ & 30 & 10 & 6 & 6 \\
\hline & 0.35 & $1 \cdot 72$ & 1.03 & 0.92 & 30 & 10 & 6 & 6 \\
\hline
\end{tabular}

$40 \mathrm{mg}$. daily, after 48 hours; the dosage was then slowly reduced so that when discharged on 11 March 1961 she was receiving $15 \mathrm{mg}$. daily. The dosage now remained at between 5 and $10 \mathrm{mg}$. daily but she was readmitted at the beginning of May 1961 having clinically relapsed, and a further serum electrophoretic strip showed a markedly elevated alpha 2 globulin fraction (Fig. 1). A glycoprotein strip reflected this abnormality in the raised alpha 2 glycoprotein (Fig. 2). Steroid therapy was increased to $60 \mathrm{mg}$. daily and she once more showed an almost immediate clinical response. Prednisone was now again slowly reduced so that by early July 1961 she was on a maintenance dose of $10 \mathrm{mg}$. daily and was clinically well. Subsequent electrophoretic studies on 16 August 1961 and on 11 October 1961 (Fig. 3) showed a normal alpha 2 globulin level but a glycoprotein strip on the latter date likewise revealed a normal alpha 2 glycoprotein (Fig. 4). Thereafter her condition began once more to fluctuate (Fig. 7) and steroid therapy required constant adjustment. Indeed in March 1962, 13 months after the initial admission, she relapsed clinically yet again and a serum electrophoretic strip on 28 March 1962 revealed a raised alpha 2 globulin fraction (Fig. 5) which was reflected in the raised alpha 2 glycoprotein (Fig. 6).

Two of these 11 patients lend emphasis to the point already made as to the diagnostic problem such cases may on occasion present. Thus the possibility of cervical spondylosis was initially entertained in patient H.B., while in patient B.L., though giant cell arteritis was indeed suspected and steroid therapy even begun, her symptoms were such that it was felt justifiable to proceed to a ventriculogram to exclude an intracranial neoplasm.

\section{DISCUSSION}

The consistent serum electrophoretic changes in these 11 patients have been found to be a considerable increase in the alpha 2 globulin fraction with a milder elevation in the alpha 1 fraction, while the albumin is decreased; the alpha 2 fraction is unequivocally and strikingly raised while the alpha 1 change may remain within the limits of normal. Such a pathological pattern is not of course pathognomonic of giant cell arteritis but rather of a general inflammatory state in which it is well known that the alpha 2 globulin is inevitably raised.

Figure 7 shows that the subsequent response to appropriate steroid therapy is of a falling alpha 2 globulin level. There is indeed a corresponding decrease in the globulins generally, but more particularly in the gamma fraction, and the balance of the decreased alpha 2 and gamma globulins is shifted to the albumin, which now rises. We were struck by the considerable decrease in the gamma globulin fraction following the start of steroid therapy in each case.

The glycoprotein strips (Figs. 2, 4, and 6) revealed convincingly how the alpha 2 glycoprotein faithfully mirrored the rise and fall of the alpha 2 globulin fraction in the serum protein strip, which in turn, as we have stressed, reflected the activity of the underlying inflammatory state.

In considering the above changes, it is of course appropriate that one should appreciate that in the elderly generally, and certainly in the age group of patients with giant cell arteritis, the globulins generally tend to be higher and the albumin relatively decreased as compared with those values found in earlier years.

It is certainly true, as the graph indeed shows, that in essence the rise and fall of the alpha 2 globulin fraction is followed closely by similar changes in the E.S.R. We would stress, however, the value of performing both investigations, particularly in those 


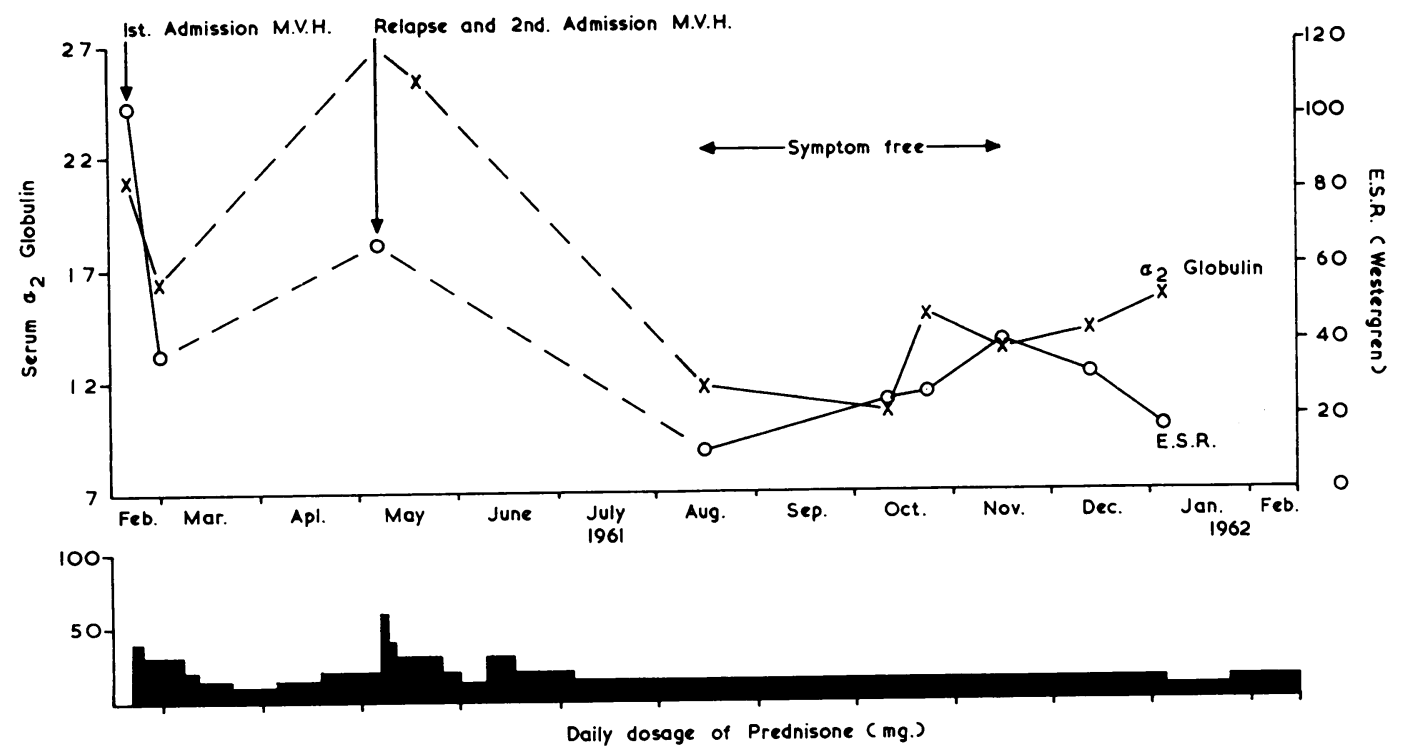

FIG. 7. Graph of alpha 2 globulin (relative values) and E.S.R. levels between February 1961 and January 1962 in $A . R$.

cases of diagnostic difficulty, for appropriate changes in the two would strongly indicate an underlying inflammatory state, and, if diagnostic suspicion or doubt existed, would justify an arterial biopsy. Such findings would not have been compatible with cervical spondylosis in patient H.B. nor with a meningioma in patient B.L. We have indeed had an opportunity to carry out serum electrophoretic studies in five patients with intracranial neoplasms (two meningiomas, two gliomas, and an haemangioblastoma) and without exception the pattern has been normal (Table II).

Yet a further aid to diagnosis in the doubtful case is an estimation of the C-reactive protein which is known to appear in the blood in inflammatory conditions and destruction of tissue. C-reactive protein was estimated in five of our patients and in four revealed a titre varying from $\frac{1}{2}$ to $\frac{1}{4}$; in the remaining patient it was negative but was assessed at a stage of inactivity.

\section{SUMMARY}

The serum electrophoretic changes are reported in 11 cases of giant cell arteritis, using a cellulose acetate technique. All showed a considerable and striking increase in the alpha 2 globulin fraction with but a minimal elevation of the other globulins and a decrease in the albumin. Appropriate steroid $\mathscr{\complement}$ therapy lowered the alpha 2 globulin and indeed $\vec{\circ}$ produced a reduction in the globulin levels generally, 3 more particularly in the gamma globulin; the balance $\vec{F}$ of the decreased globulins was shifted to the albumin fraction, which rose.

TABLE II

SERUM ELECTROPHORETIC FINDINGS IN FIVE CASES OF INTRACRANIAL NEOPLASM

Total Protein (g. \%)
Absolute Values

Albumin Globulins

$\alpha_{1} \quad \beta$

0.28

$0 \cdot 10 / 0 \cdot 4$

$0 \cdot 21$

$0 \cdot 34$

$0 \cdot 22$

0.03
$6 \cdot 99$

$7 \cdot 37$

$3 \cdot 57$

$3 \cdot 48$
$4 \cdot 07$

Meningioma This strip was normal, values not calculated 
Glycoprotein strips demonstrated the alpha 2 glycoprotein as faithfully mirroring the rise and fall of the alpha 2 globulin fraction in the serum protein strip which, in turn, reflected the activity of the underlying inflammatory state.

A markedly raised alpha 2 globulin fraction on serum electrophoresis would strongly indicate an underlying inflammatory state, and, certainly in conjunction with an elevated E.S.R., would justify an appropriate arterial biopsy, should suspicion or doubt as to the possibility of giant cell arteritis be present; the presence of C-reactive protein in the blood would further support an inflammatory state. Such a combination of changes would not be compatible with an intracranial neoplasm.

In cases of giant cell arteritis continuing inflammation is better assessed by serum electrophoresis and the E.S.R. than it is by the patient's symptomatic response to therapy, and of these two investigations the alpha 2 globulin change is the more sensitive reflector of smouldering activity. The need and amount of therapy required are better assessed by these investigations than by the patient's clinical response alone.

We are deeply indebted to Dr. J. Kohn for his suggestion to study the C-reactive protein in this condition and for his kindness in carrying out this investigation on five of these patients.
We would like to acknowledge the helpful advice and encouragement we have received throughout this study from Dr. W. McMenemey and from various other members of the consultant staff of Maida Vale Hospital for allowing us access to their patients. We are grateful to Dr. G. Parsons-Smith and Mr. Leslie Oliver for allowing us to include patients under their care at the West End Hospital, to Dr. G. Melton, of Highlands General Hospital, under whose care patient B.L. was admitted before her transfer to the West End Hospital. Similarly we would like to thank Dr. J. Bevan-Jones of Mayday Hospital, Croydon, for permitting us to include patient J.F. One of us (K.S.) is indebted to the Multiple Sclerosis Society for a grant.

\section{REFERENCES}

Bagratuni, L. (1953). Ann. rheum. Dis., 12, 98. (1956). Lancet, 2, 694.

Björkman, S. E. (1958). Ibid., 2, 935.

Bodman, J. (1957), Lab. Pract, 6, 517.

Cardell, B. S., and Hanley, T. (1951). J. Path. Bact., 63, 587.

Cooke, W. T., Cloake, P. C. P., Govan, A. D. T., and Colbeck, J. C. (1946). Ouart. J. Med., 15, 47.

Crompton, M. R. (1961). Wld Neurol., 2, 237.

Gilmour, J. R. (1941). J. Path. Bact., 53, 263.

Heptinstall, R. H., Porter, K. A., and Barkley, H. (1954). Ibid., 67, 507.

Hollenhorst, R. W., Brown, J. R., Wagener, H. P., and Shick, R. M. (1960). Neurology (Minneap.), 10, 507.

Kohn, J. (1958). Clin. chim. Acta, 3, 450. (1960). Proc. 8th Colloq. Biol. Fluids, Bruges, 1960, 315.

MacGregor, G. A. (1961). Lancet, 2, 1160.

Paulley, J. W., and Hughes, J. P. (1960). Brit. med. J., 2, 1562.

Russell, R. W. Ross (1959). Quart. J. Med., 28, 471. 